\title{
REVIEW
}

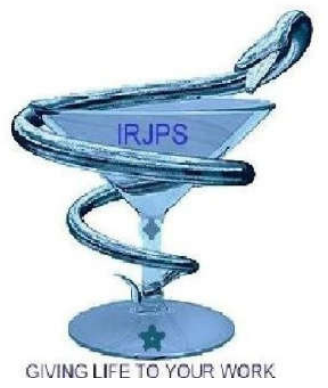

\section{ANTIPSORIATIC THERAPY: DISCOVERING NEW HORIZONS}

\author{
Pritee Gupta*, Akash Saini \\ Department of Pharmaceutical Sciences, Dr. H. S. Gour Central University, Sagar, Madhya Pradesh, India.
}

\begin{abstract}
Psoriasis is inflammatory skin disorder, which is chronic and an autoimmune disease and affect the life of approximately $2 \%$ of the world population. There are various topical treatments which has been used such as topical steroids, dithranoletc andall shows very low efficacy, poor solubility andhas low aesthetic and cosmetic appeal, ultimately results in low patient compliance on the other hand systemic therapiesproduces significant side effects. Successive progress in the development of new drug delivery system such as colloidal drug delivery systems has led to effective and safe treatment of psoriasis. Colloidal carriers such as vesicular and particulate carriers includes liposome, emulsome, transferosomes, ethosomes, SLNs, microspheres, micelles, dendrimers etc. have gained unique and impotant position in drug delivery system. Several approaches are done for treatment of psoriasis but, rate of success is always a questionwhen conventional system is concerned for the treatment of psoriasis. Present article is an attempt to improve the therapy of psoriasis related to its pathogenesis and offers disease management of this, treatment of psoriasis and the pharmaceutical approach was done for effective and safe drug delivery for the treatment and management of this disease. It will also discuss details about topical drug delivery in general and its challenges in designing effective drug delivery against psoriasis.
\end{abstract}

KEYWORDS: Psoriasis, Colloidal carriers, challenges, Nanotechnology

Corresponding Author: Pritee Gupta

E-mail: gupta.pg.priti@gmail.com
Indian Research Journal of Pharmacy and Science; 14(2017)1119-1138; Journal Home Page: https://www.irjps.in DOI: 10.21276/irjps.2017.4.3.6 


\section{INTRODUCTION}

Psoriasis is inflammatory skin disorder which is a chronic and an autoimmune disease and affects approximately $2 \%$ of the world population ${ }^{1}$. It basically involves immoderate growth and discrimination of keratinocytes and thus causes distinct, red, scaly plaques which appear on the skin and therefore also known as papulosquamous disorder. It is caused by activation of $\mathrm{T}$ lymphocytes in dermis (primarily CD4+ cells) and epidermis and thus known as immunologically mediated disease $^{2}$.About $80 \%$ of people are suffering from psoriasis vulgaris and are treated topically. The conventional topical aid incontrolling psoriasis are having several limitations, for which the novel carriers are reported to deceive with safe and long term use ${ }^{3}$. Novel carrier such as liposome, SLN, emulsomes, NLC, nanoemulsion and ethosomes have brought us closer to achieve the goal for safe and effective treatment of this disease ${ }^{4}$.

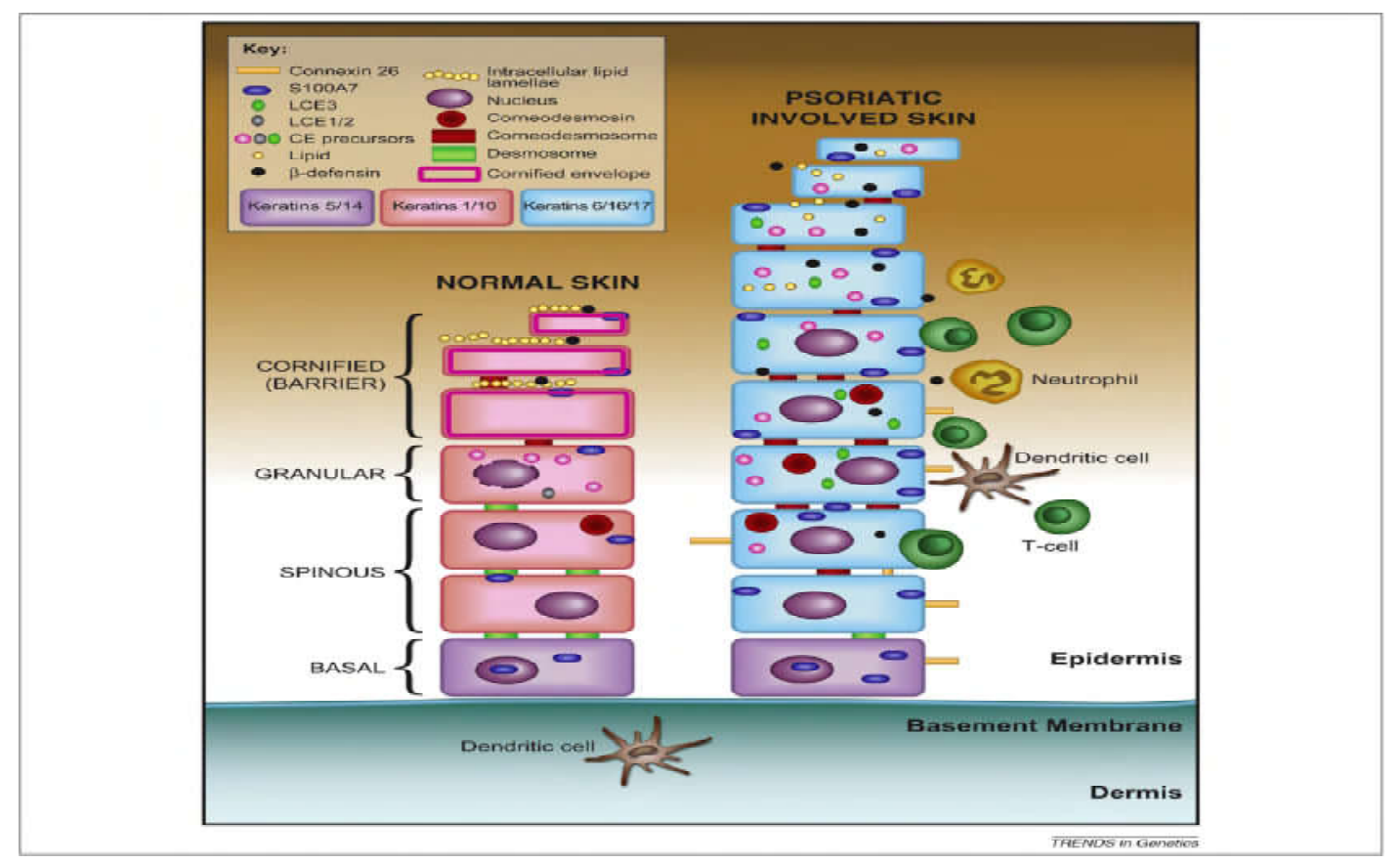

Fig. 1: Difference between healthy and psoriatic skin ${ }^{103}$

\section{EPIDEMIOLOGY}

Psoriasis varies considerably among world population.In united statesapprox $2 \%$ of the population is effected with this .High rate of psoriasis have been reported in people of the Faroe Islands where $2.8 \%$ of the population is effected ${ }^{5}$. Psoriasis effect almost all the genders equally. Survey on monozygotic twins tells that there is $70 \%$ chance of developing psoriasis in twin if the index twins have psoriasis. Henseler and Christophers examined a set of 2147 patients and reported that the psoriasis is of two types, i.e. type I and type II ${ }^{6}$. Type I induce at or before age of 40 years, type II induce after the age of 40 years. In more than $75 \%$ of cases there is induction of Type I. Type I is more caustic than Type II. Psoriatic disease has strong association with human leukocyte antigen - Cw6 in patient with early begining, when compare with later ${ }^{7}$.

\section{PATHOPHYSIOLOGY:}

Psoriasis is characterized by expansion and abnormal growth of epidermal keratinocytes, $\mathrm{T}$ lymphocyte mainly consist of lymphocyte infilterationand have specific vascular changes in endothelial in the microvasculature of dermis and thus includes limited neoangiogenesis, dilation of capillary and high 1 venule formation in endothelia, all this causes visible redness in psoriatic skin ${ }^{8}$ 


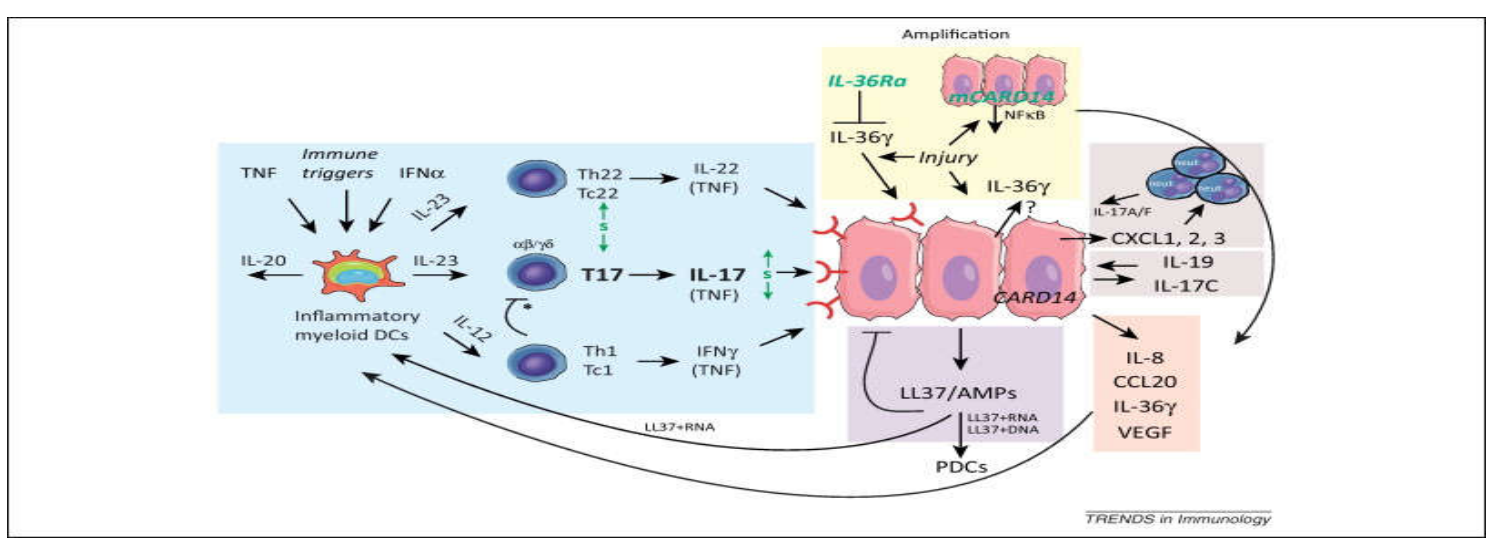

Fig. 2: Pathophysiology of psoriasis ${ }^{104}$

Antigen which is present on the major histocompatibility complex (MHC I or II)are recognized by specific T-cell present on receptor or by the APC. An activated T cell expands and enters in blood circulation through interaction between LFA-1 and ICAM-1, and expelthrough diapedesisin the endothelium at site of inflammation in the skin'.After this, the T-cells transmit in the immunologic process through the secretion of proinflammatory (type 1 or Th1) cytokines, which include interleukin (IL)-1, tumor necrosis factor (TNF)- $\alpha$, and interferon (IFN)- $\gamma$. These secretion results in the formation of Th2 cytokine including IL4, IL-10 and IL-1 ${ }^{10}$. Each cytokine down regulates the other's responses. The final results of this is the formation of the psoriatic plaquethrough proliferation of keratinocytes, an thus their is increase in the activity and migration of other inflammatory cells and vascular changes ${ }^{11}$.

Table. 1: Types Of Psoriasis ${ }^{12}$ :

\begin{tabular}{|c|c|l|l|}
\hline SL.NO & TYPES & \multicolumn{1}{|c|}{ FEATURES } & \multicolumn{1}{c|}{ SITE EFFECTED } \\
\hline $\mathbf{1}$ & PLAQUE & $\begin{array}{l}\text { This is the most common form of psoriasis. hair } \\
\text { loss is permanent, and occur when excessive } \\
\text { traction is applied to scale of hair. }\end{array}$ & $\begin{array}{l}\text { Extensor sufaces(elbows and } \\
\text { knees) most common } \\
\text { distribution. Lower back, scalp, } \\
\text { and nails (frequently effected) }\end{array}$ \\
\hline $\mathbf{2}$ & GUTTATE & $\begin{array}{l}\text { Small salmon pink papules usually with a fine } \\
\text { scale are characteristics features. }\end{array}$ & $\begin{array}{l}\text { Mostly occur on trunk and } \\
\text { proximal extremities. }\end{array}$ \\
\hline $\mathbf{3}$ & ERYTHRODERMA & $\begin{array}{l}\text { Total involvement of the skin take place by } \\
\text { active psoriasis. It can be precipitated by } \\
\text { infection, low calcium withdrawal of oral } \\
\text { corticosteroids an certain medication including } \\
\text { lithium, antimalarial and IL -2 }\end{array}$ & $\begin{array}{l}\text { redness and inflammation on the } \\
\text { skin }\end{array}$ \\
\hline $\mathbf{4}$ & FLEXUAL & $\begin{array}{l}\text { It is erythematous, and not usually scaly and has } \\
\text { different skin lesion. }\end{array}$ & $\begin{array}{l}\text { Trunks and limbs. Also effecting } \\
\text { the flexures perineal and axillary } \\
\text { folds. }\end{array}$ \\
\hline $\mathbf{5}$ & PUSTULAR & $\begin{array}{l}\text { Generalized form is also known as Zumbusch's } \\
\text { psoriasis. Due to formation of pustules and } \\
\text { scaling redness o skin takes place. }\end{array}$ & $\begin{array}{l}\text { hands and feet are the site which } \\
\text { is effected }\end{array}$ \\
\hline
\end{tabular}




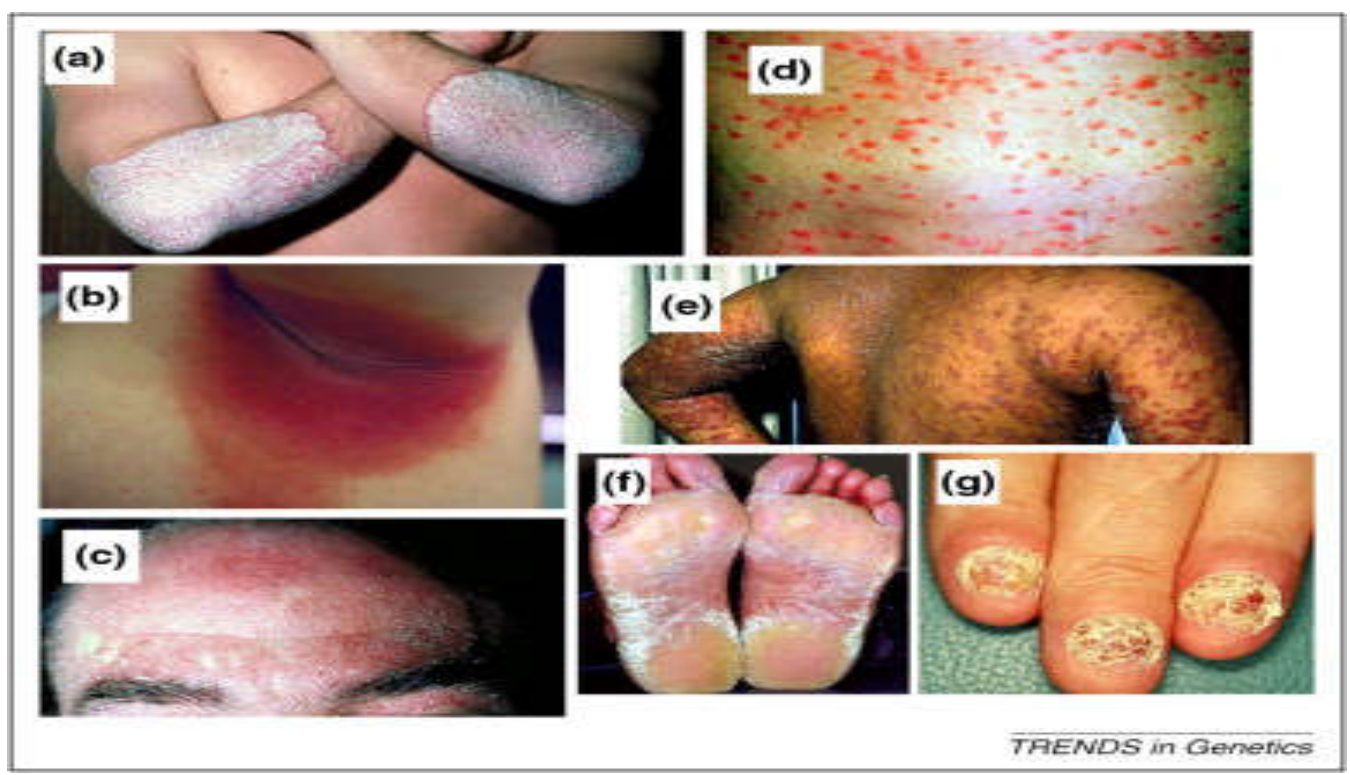

Fig. 3: Types of psoriasis ${ }^{105}$

\section{TREATMENT OF PSORIASIS:}

Currently there are varioustreatment approved across world which include photo chemo therapy, topical therapy drugs likeCiclosporin,dithranoletc, systemic treatment like methotrexate and oral retinoid therapy ${ }^{14}$.

Approval of Systemic therapies, like hydroxyureaetc across the countries for the treatment of psoriasis is very low. Moderate to severe psoriasis treatment is often initiated by photo chemo therapy. Combinational treatment such as (topical, phototherapy and systemic) is very common, and although plays an empirical role. In some placemetho- trexate is often prescribed only when no other drug is effective; however, in other countries methotrexate is used as a first-line systemic treatment for severe psoriasis. In many other countries when there is concurrent acute psoriatic arthritis, methotrexate is used as first-line systemic treatment. In Italy, the most commonly used systemic therapy for psoriasis is ciclosporin, when there is resistant to classical therapies methotrexate is usually reserved for treatment. However in some countries Physicians used to combine ciclosporin with methotrexate. Retinoids seem to be the last choice in several European countries and are usually not used in combination, as monotherapy appears to have high efficacy for chronic plaque psoriasis ${ }^{15}$

Table. 2: Treatments of Psoriasis

\begin{tabular}{|c|c|c|}
\hline Sl. No & Categories & Drugs Used \\
\hline 1. & Topical Therapies & $\begin{array}{l}\text { * Vitamin D derivatives } \\
* \quad \text { Coal tar preparations } \\
* \quad \text { Dithranol } \\
* \quad \text { Vitamin A derivatives }\end{array}$ \\
\hline 2. & Phototherapy & * $\quad$ Psoralens With UVA \\
\hline 3. & Systemic Treatment & $\begin{array}{ll}* & \text { Methotrexate } \\
* & \text { Ciclosporin } \\
* & \text { Acitretin } \\
* & \text { Hydroxycarbamide }\end{array}$ \\
\hline
\end{tabular}




\begin{tabular}{|l|l|l|}
\hline & & \\
\hline 4. & Biological & $*$ Etanercept \\
& & $*$ Infliximab \\
& & $*$ Adalimumab \\
& & $*$ Alefacept \\
& & Efalizumab \\
\hline
\end{tabular}

\section{COMMON DRUGS USED MAINLY FOR PSORIASIS TREATMENT 161718192021 :}

There are various commonly used drugs for treatment of moderate and severe psoriasis. There are various topical agents which are usually used for mild psoriasis, sometimes they are combined with phototherapy. Sometimes combinations of topical and systemic therapy are used to treat moderate and severe psoriasis. When the effects of topical agents or phototherapy are not effective, systemic agents are added and should be considered. To treat severe psoriasis biological agents are used and are usually used when patients fail to respond to conventional systemic treatment and life of patient is seriously affected. Topical corticosteroids and vitamin D3 analogs are the mainly used for treatment of mild psoriasis. Ultraviolet B (UVB) therapy is widely used for moderate to severe psoriasis. However in severe casesAcitretin, cyclosporin A (CsA), and other immunosuppressive agents are used. Etanercept and infliximab have also been successfully used in patients with severe psoriasis.

Table. 3: Common Drugs Used Mainly For Psoriasis Treatment 161718192021

\begin{tabular}{|c|c|c|c|c|}
\hline S.No & Drugs & Features & Mechanism Of Action & Adverse Effect \\
\hline 1 & Dithranol & $\begin{array}{l}\text { It is most effective topical } \\
\text { therapy in psoriasis. The } \\
\text { oxidation products have very } \\
\text { low or no effect on psoriasis. }\end{array}$ & $\begin{array}{l}\text { It accumulates in mitochondria } \\
\text { where it interacts with the } \\
\text { energy which is supply to the } \\
\text { cell, through oxidation of } \\
\text { dithranol free radicals are } \\
\text { released and reduce DNA } \\
\text { replication and slows the } \\
\text { excessive rate of cell division } \\
\text { that occurs in psoriatic plaques. }\end{array}$ & $\begin{array}{l}\text { 1. Stains the skin } \\
\text { and permanently } \\
\text { stains clothing } \\
\text { fabrics. } \\
2 \text {. Burning } \\
\text { sensation and } \\
\text { irritation. }\end{array}$ \\
\hline 2 & Methotrexate & $\begin{array}{l}\text { Methotrexate (MTX) is first } \\
\text { line drug used systemically in } \\
\text { psoriasis. }\end{array}$ & $\begin{array}{l}\text { Inhibits } \\
\text { dihydrofolatereductase(Fplic } \\
\text { acid required for the de novo } \\
\text { synthesis of of the nucleoside } \\
\text { thymidine requires for DNA } \\
\text { synthesis. }\end{array}$ & $\begin{array}{l}\text { Anemia, } \\
\text { neutropenia, } \\
\text { bruising nausea } \\
\text { and vomiting, } \\
\text { dermatitis } \\
\text { headache and } \\
\text { alopecia. }\end{array}$ \\
\hline 3 & Tacrolimus & $\begin{array}{l}\text { It is effective and well- } \\
\text { tolerated immunosuppressant, } \\
\text { and plays important role in the } \\
\text { treatment of chronic plaque- } \\
\text { psoriasis }\end{array}$ & $\begin{array}{l}\text { Topically inflammation is } \\
\text { suppressed and is effective.It } \\
\text { binds withimmunophilin } \\
\text { FKBP12 and creating a new } \\
\text { complexand thus reduces } \\
\text { peptidyl- prolylisomerase } \\
\text { activity. This complex inhibit } \\
\text { calcineurin thus inhibits T- } \\
\text { lymphocytesignal transduction } \\
\text { and IL-2 transcription. }\end{array}$ & 1.Cancer risk \\
\hline
\end{tabular}




\begin{tabular}{|c|c|c|c|c|}
\hline 4 & Psoralen & $\begin{array}{l}\text { Psoralen is applied topically } \\
\text { or taken orally to sensitize the } \\
\text { skin, followed by UVA } \\
\text { exposure. }\end{array}$ & $\begin{array}{l}\text { The psoralens molecule } \\
\text { intercalates between DNA base } \\
\text { pairs but also has effect on the } \\
\text { cell membrane. }\end{array}$ & $\begin{array}{lr}\text { Nausea } & \text { most } \\
\text { common, } & \text { skin } \\
\text { cancer, asal } & \text { cell } \\
\text { carcinoma } & \end{array}$ \\
\hline 5 & $\begin{array}{l}\text { Cyclosporin- } \\
\text { A }\end{array}$ & $\begin{array}{l}\text { Cyclosporin A (CsA) shows } \\
\text { their action both through oral } \\
\text { as well as topical route. It is } \\
\text { having very high molecular } \\
\text { weight (more than } 500 \text { Da) } \\
\text { and limited cutaneous } \\
\text { permeation. }\end{array}$ & $\begin{array}{l}\text { mitochondria pore opening is } \\
\text { prevented thus inhibiting } \\
\text { release of cytochrome c a } \\
\text { potent apoptotic stimulation } \\
\text { factor }\end{array}$ & $\begin{array}{l}\text { Hyperplasia, } \\
\text { ulcers, fever, } \\
\text { vomiting diarrhea, } \\
\text { high lood } \\
\text { pressure, } \\
\text { pancreatitis etc }\end{array}$ \\
\hline 6 & $\begin{array}{l}\text { VITAMIN D } \\
\text { ANALOGS }\end{array}$ & $\begin{array}{l}\text { Calcipotriol, maxacalcitol, } \\
\text { tacalcitol, and calcitriol are } \\
\text { Vitamin D3 analogues and } \\
\text { shows their role in the } \\
\text { treatment of mild-to-moderate } \\
\text { plaque psoriasis }\end{array}$ & $\begin{array}{l}\text { They bind with VDR receptor. } \\
\text { VDR modulates the T cell gene } \\
\text { transcription of cell } \\
\text { differentiation and cell } \\
\text { proliferation related genes. }\end{array}$ & 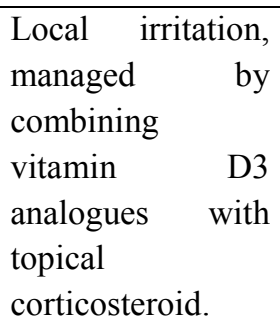 \\
\hline 7 & Coal Tar & $\begin{array}{l}\text { it is valuable, safe, and } \\
\text { inexpensive treatment of } \\
\text { people with psoriasis. Coal } \\
\text { concentration between } 0.5 \text { to } \\
5 \% \text { are safe and effective for } \\
\text { psoriasis }\end{array}$ & $\begin{array}{l}\text { Normalizes epidermal growth } \\
\text { and reduce scaling }\end{array}$ & $\begin{array}{l}\text { It causes mild } \\
\text { burning or skin } \\
\text { irritation it also } \\
\text { stains clothing } \\
\text { and skin. }\end{array}$ \\
\hline 8 & Retinoids & $\begin{array}{l}\text { These are widely used drug in } \\
\text { the topical treatment of acne, } \\
\text { photo-aged skin, psoriasis and } \\
\text { other skin disorders. In } \\
\text { various types of psoriasis } \\
\text { efficacy of aromatic retinoid } \\
\text { is marked by the more rapid } \\
\text { response for the pustular } \\
\text { variety. }\end{array}$ & $\begin{array}{l}\text { Shows modulating and } \\
\text { normalizing effect on the } \\
\text { proliferation and differentiation } \\
\text { of the epidermis. In dermal cell } \\
\text { componentsimmunomodulating } \\
\text { effects on have also seen. }\end{array}$ & \\
\hline
\end{tabular}

\section{CURRENT THERAPY IN PSORIASIS:}

Understanding of the pathophysiology of psoriasis has changed from that of keratinocytes disease to a $\mathrm{T}$ cell-mediated disease now usually considered as a systemic chronic inflammatory disease which plays important role for the immunology system and has changes the treatment mode over the years.Nonselective treatments such as corticosteroids, Hydroxycarbamide, and acitretin, was started first then moving on to more selective treatments such as cyclosporine and at last the highly selective biological therapies are used ${ }^{22}$. For the management of moderate-to-severe psoriasistumour necrosis factor 
(TNF)- $\alpha$ inhibitors are introduced and changed the understanding of pathophysiology of psoriasis.Inhibition of the binding of lymphocyte function-associated antigen-3 (LFA-3) to CD2 (e.g. with alefacept) or via blocking of the CD11a chain of LFA-1 and inhibition of cell adhesion (e.g. with efalizumab) ${ }^{23}$ are the another method of treating psoriasis which targets $\mathrm{T}$ cells.

Various biological products are used for psoriatic treatment which modifies the pro inflammatory cytokine levels and increase the expression of specific CYP enzymes as well as the exposure of CYP enzyme substrates, which is considered psoriasis disease-drug-drug interactions (diseaseDDI $)^{24}$.But the major disadvantages of using biological products are that they are costly and $t$ repeated injections are also require and some patients experience tacaphylaxis ${ }^{25}$. For the treatment of plaque psoriasis new biologics and small molecules are briefly discussed in the below section.

1. IL-12/23 inhibitor:They are heterodimeric pleiotropic cytokines each consisting of 2 subunits and are named according to their $\operatorname{size}^{26}$. The production of IL12are through macrophages and B cells and shows to have multiple effects on $\mathrm{T}$ cells and natural killer (NK) cells, whereas for differentiation of Th17 lymphocyte IL-23 is essential.Drugs that inhibits IL-12/23 are discussed below:

a. Briakinumab: They are human monoclonal antibody and inhibits IL-12/23 which targets the common p40 subunit of IL-12 and IL-23. it was found that $82 \%$ patients treated with briakinumabachieved a 75\% reduction in their baseline Psoriasis Area Severity Index score at week 24 in a Phase III clinical trial and compared with $40 \%$ methotrexate treated patients. ${ }^{27}$ Serious infections, non-melanoma skin cancers and cardiovascular eventsSome adverse effects which were reported, suggesting that their is need for surveyance with wider use of briakinumab ${ }^{28}$. Overall, it is demonstrated that for psoriatic effective treatmentbriakinumab is highly effective and suggests that continued vigilance be used in evaluating the safety profile of this drug. b. Ustekinumab: They are also human monoclonal antibody which inhibits IL-12/23. It is approved over the world for the treatment of moderate-to-severe plaque psoriasis. These are anticytokinins. ${ }^{29}$

2. IL-17 inhibitors: IL-17A, IL- 17B, IL-17C, IL17D, IL-17E (also called IL-25), and IL-17F all are the members of the IL-17 family. All members of this family have a protein structure which is similar with 4 highly conserved cysteine residues and also have similarity with other known cytokines ${ }^{30}$.In psoriasis pathogenesis it is a key "driver" pro-inflammatory cytokine $^{31}$. It can activate hyperproliferation of keratinocytes and produces antimicrobial peptides, such as cytokines, and chemokines, which, in turn, activate other immune cells leading to development of psoriasis inflammation ${ }^{31}$. Some inhibitors of IL-17 are discussed below.

\section{a. Secukinumab :}

It is a human monoclonal antibody $\operatorname{IgG} 1 \kappa$ that binds and neutraliseswith IL-17A. A 12 weeks study reported that treatment of patients with subcutaneous secukinumab resulted in response rates higher as compared with placebo.

\section{b. Ixekizumab:}

It is a IgG4 human monoclonal antibody which neutralises IL-17A. After 12 weeks, it is reported that the percentage of patients with moderate-to-severe psoriasis who had a PASI75 or PASI90 was increases in the groups receiving subcutaneous ixekizumab ${ }^{33}$.

\section{c. Brodalumab:}

It acts as an antagonist to the receptor subunit of IL17A, IL-17F, and IL-17A/F heterodimer ligands and works in a slightly different way like other IL-17 inhibitors ${ }^{34}$.

\section{Anti-tumour necrosis factor agents:} Certolizumabpegol a new TNF blocker has been introduced and inhibits TNF- $\alpha$. They are conjugated

with polyethylene glycol. Like other anti-TNF monoclonal antibodies they lacks a fragment crystallizable portion and, consequently, does not induce antibody-dependent cytotoxicity. ${ }^{35}$ These drugs binds with soluble and membrane-bound TNF- 
$\alpha$, and blocks crucial events associated with psoriatic inflammation ${ }^{36}$.

\section{Small molecules:}

For psoriasis treatment various small molecules are introduced, which includesphosphodiesterase (PDE) inhibitors, JAK inhibitors, and A3 adenosine receptor (A3AR) agonists. They are as follows:

\section{a. Phosphodiesterase inhibitors:}

The breakdown of 3'-5'-cyclic adenosine monophosphate (cAMP) to AMP is catalyse by this enzyme. Increase in concentration of cAMPin addition with inhibition PDE-4 reduces the production of pro-inflammatory mediators which are involved in psoriasis inflammation, such as TNF- $\alpha$ and IL-23, and increase the production of antiinflammatory mediators, such as IL- $10{ }^{37}$.Their are various small molecules which act as a PDE-4 blocker. Apremilast is one of this and was approved by the FDA for treatment psoriatic arthritis. Intestinal intolerability, a well-known adverse event with PDE4 inhibitors, was reported ${ }^{38}$.

\section{b. Janus kinase inhibitors(JAK):}

It is protein tyrosine kinases (TYKs) enzymes that are essential for the beginning of activated signalling pathways of cytokine. These enzymes act as activator of transcription (STAT) proteins and also help in

activation of the signal transducer and phosphorylation of protein. These enzymes are of 4 types: JAK1, JAK2, JAK3, and TYK2. JAKs are intracytoplasmic portion of cytokine receptors. Tofacitinib act as inhibitor of the JAK1 and JAK3signalling pathway. It is approved for the treatment of rheumatoid arthritis but not by the European regulatory agencies because of low efficacy and safety ${ }^{39}$.

\section{* Tofacitinib :}

Tofacitinib was generally well-tolerated but some side-effects were reported. The most frequently reported AEs were infections (nasopharyngitis, sinusitis, upper respiratory tract infection ${ }^{40}$.

\section{* Ruxoutinib:}

Used for myeloproliferative disorders and are used in systemic treatment.It acts as an inhibitor of JAK1 and JAK2. Recently, topical formulations of ruxolitinib have been developed for psoriatic therapy ${ }^{41}$.

\section{A3 adenosine receptor agonists:}

These are $\mathrm{G}$ protein-coupled receptors and are involved in a variety of intracellular signalling pathways and physiological functions. Adenosine act as natural ligand of $\mathrm{A} 3 \mathrm{AR}$ receptors .These are highly found in peripheral blood mononuclear cells isolated from patients with psoriasis ${ }^{42}$.

\section{NANOTECHNOLOGY BASED APPROACHES FOR EFFICIENT DRUG DELIVERY:}

During psoriatc treatment it was found to be unsatisfied or moderately satisfied with their current treatment. It is because of uneffective delivery of drugs and undesirable skin irritation due to topical treatments is the main reasons for lack of patient compliance $^{44}$.

Through the development of Nanotechnologywe can achieve a continuous delivery of drugs to a target and are site specific and at act as a predictable and reproducible kinetics over an extended period of time in the circulation. The development of this concept includes minimization of drug related side effects due to controlled therapeutic blood levels, patient compliance due to reduction dose frequency. Various novel vesicular drug delivery systems have been introduced for various routes of administration, to achieve site specificand sustained drug delivery ${ }^{45}$.If the drugs are targets to its specific site of action it seems to improve the access amount of drug which further helps inlow toxicity and also improves the therapeutic index. This delivery system also shows reductionin systemic side effects to a great extent ${ }^{46}$. These systems offer various advantages over conventional delivery system such as reduction in drug degradation and drug loss, high bioavailability, prevention through harmful toxic effects, versatility and flexibility in nature, better patient compliance ${ }^{47}$. 
There are various types of nanotechnology based

treatment and classified into various groups. approaches for efficient drug delivery in psoriasis

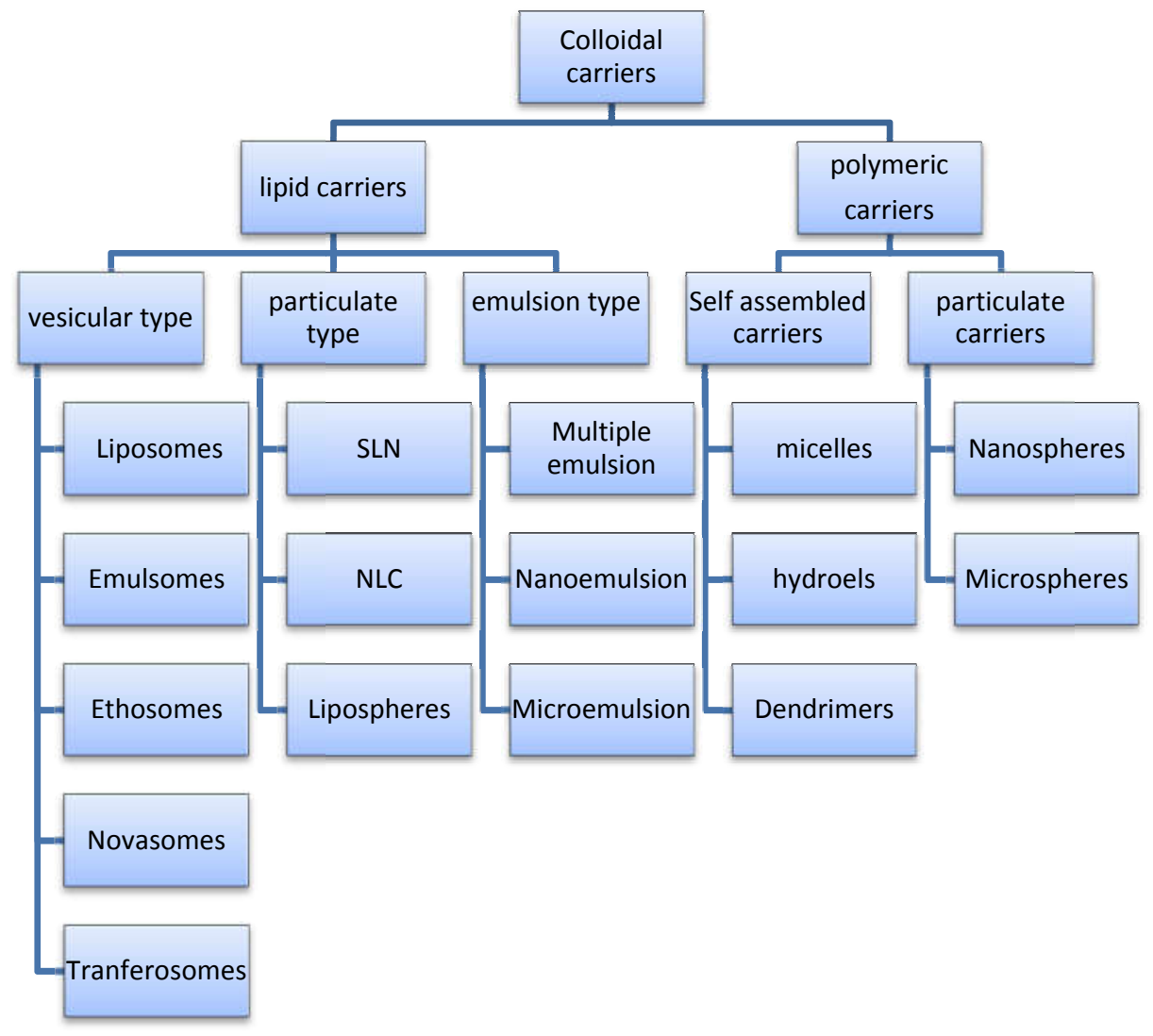

Fig. 4: Nanotechnology based Approach

\section{LIPID CARRIERS:}
I. Vesicular type
ii. Particulate types
iii. Emulsion types

1. Vesicular type: Drugs are delivered through various routes of administration, number of vesicular drug delivery systems have been develop to achieve site specific and controlled\& sustained drug delivery. These system are used to increase therapeutic index, high solubility and stability and degradation of drug molecules ${ }^{50}$. Their are various types of vesicular carriers which are used for effective delivery and targeting of drug molecules. a. Liposomes: These are microscopic structures consisting of lipid bilayer with aqueous inner core. They are having various advantages and are superior then conventional dosage form. Phospholipid are one of the major component in this and thus play a promising role in drug delivery of lipophilic drug ${ }^{51}$.

Pathomthat, S et al 2012reported thatthe liposomes in which methotrexate is entrapped helps to enhanced the skin permeability characterized by the higher concentration and MTX are accumulated in the epidermis and dermis layers of skin. The increased permeability of MTX-entrapped liposomes was because of deformable characteristic of oleic acid and act as a skin penetration enhancer of ${ }^{\mathbf{5 2}}$.

Saraswat, A et al.2007 reported that $0.5 \%$ dithranol loaded liposomal gel is effective in plaque psoriasis and have no adverse effects. It is coupled with low 
fabric and has easy washability, dithranol loaded liposomal gel has much more potential to be acceptable by the patients and physicians than currently available formulations ${ }^{\mathbf{5 3}}$.

\section{b. Ethosomes}

These are lipid vesicles which are soft and malleable in nature and are composed of phospholipids, alcohol in high concentration 20 to $45 \%$ and water. They work by the mechanism of permeation through skin due to high deformability. This carrier provide effective delivery of lipophilic, hydrophilic as well as ampiphillic drug ${ }^{54}$.

Rakesh R.et al. 2011 reported that they improve the penetration of drugs through the skin barrier and thereby increase the efficacy. The ethosomes are versatile in nature and are effective for transdermal as well as topical drug delivery of few drugs such asminoxidil, testosterone,etc. Delivery of some antigens such as Hepatitis B surface antigen and DNA through ethosomeshelps in transcutaneous immunization and gene therapy. Several phytochemicals and herbal extracts have been successfully delivered with the help ofethosomes and have various advantages over conventional drug delivery systems. ${ }^{\mathbf{5 5}}$

\section{c. Emulsome:}

Emulsomes are vesicular type of drug delivery system. They have the characterstics of both liposomes and emulsion. Emulsomes are one of delivery system which is formulated in absence of ionic or non ionic, non natural synthetic surfactant or cosurfactant. Due to high lecithin contentthey are stable in nature. Their hydrophobic core are surrounded and stabilized by one or more layers of phospholipids molecule ${ }^{56}$.

Gupta S et al. 2007 reported that Amphotericin B loadedemulsomes (both plain and Opalmitoylmannan (OPM) coated) shows better antileishmanial activity. Their study confirms that the efficacy of Amphotericin B is increased if the drug is coated with OPM grafted emulsome form ${ }^{57}$.

Raza K et al 2012reported dithranol loaded emulsomes have high skin permeation flux as well as high skin retention. An improved antipsoriatic activity and practically devoid of any skin irritation has been reported. Thedithranol loaded emulsomesenhanced the pharmacodynamic activity, and also made the drug available in the skin. Thus, this carrier system improves the duration as well as the onset of action ofdithranol. Their systematic study helps in developing "optimized" nano colloidal formulations for topical. The lipids (namely Compritol and phospholipid) showed considerable influence on emulsomalfeatures and thus improves entrapment efficiency, particle size, skin permeation and retention ${ }^{58}$.

\section{d. Novasome :}

These are micro vesicle which are formed from phospholipids which are biocompatible in nature and are ampiphilic in nature. These drug delivery systems are effective in nature for a variety of drugs. There is no incompatibility problem with this carrier due to incorporation of incompatible drugs between the bilayers. Their is increase in the efficacy and efficiency with this for the treatment

with almost no side effects. They are natural and do not cause any kind of cytotoxicity.Novasomes can be formulated to the desired release action and absorption level. It is one of the most effective method to treat skin disorders.

Agarwal et al. 2013 reported that novasomes helps to increase the stability of product, extended shelf life from weeks to sometimes years, prevention of oxidation and emulsification, and permits isolating antagonistic ingredients within the formulation until use. The control release of active ingredients through heat, pressure and/or time also enables through novasomes. ${ }^{59}$.

2. Particulate carrier: In this systemthere is either disperstion of drug in lipid matrix or dissolved in lipid matrix. Thus due to this they prevent rapid drug release and allow controlled and sustained release of drug. There is high drug loading and stability is increased. These carriers providesthe effective and safe drug delivery in various skin disorders including psoriasis. Various particulate lipid based colloidal 
carriers that have found application in antipsoriatic drug delivery ${ }^{60}$. They are as follow

a. Solid lipid nanoparticle: These are novel carriers used for delivery of drug at a specific target. It is composed of triglycerides or other glyceride and waxes which are solid in nature.

Sonawane $\mathrm{R}$ et alreported that Betamethasone dipropionate and calcipotriol loaded solid lipid nanoparticles distribution of drugs to epidermal and dermal region of skin was observed which is essential for safe and effective anti-psoriatic therapy. Draize patch test and TEWL demonstrated negligible skin irritation and better skin tolerability of SLNs. The in vitro $\mathrm{HaCaT}$ cell line study demonstrated that SLNs delayed the abrupt growth of keratinocytes, while in vivo mouse tail model showed that SLNs gel significantly decreased the epidermal thickness and increased melanocyte count in comparison to commercial Daivobet ointment ${ }^{61}$.

b. Nanostructured lipid carrier: NLC are modern or new generation type of solid lipid nanoparticles. These are prepared when solid lipids are mixed with incompatible lipids leading to a lipid matrix. NLC are used in various types of skin diseases such as psoriasis, eczema etc and generally used for topical delivery drug ${ }^{62}$.

Shinde. G. et al. 2013 reported about nanostructured lipid carrier (NLC) loaded gel for psoriasis and reported optimized NLCBG batch enhanced the permeation, sustained the drug release and enhanced the drug release at the site of action. The optimized NLCBG was compared with marketed preparation for skin permeation and skin retention study which concludes that optimized formulation better result than marketed preparation. Skin irritation study was also shown that no irritation on skin and show prolong release up to $24 \mathrm{hr}^{63}$.

Agrawal.Y.et al.2010. reported that its use enhanced the therapeutic response and topical treatment of psoriasis, Acitretin loaded NLC gel were observed and concluded they have low adverse effects during therapy, have better patient compliance. Thus, Acitretin loaded NLC gel considered as a supplementary to oral therapy, particularly in last stage of psoriatic treatment. ${ }^{64}$

3. Emulsion based carrier: These are emulsion based carriers in which dispersion of two or more immiscible liquid are involved which are further stabilized by surfactant or co surfactant.

a. Micro emulsion: These are thermodynamically stable emulsion. These are biphasic in nature and dispersions of two immiscible liquids which are stabilized by an interfacial film of surfactant molecules in conjunction with a co-surfactant take place. These are of 2 types oil-in water $(\mathrm{O} / \mathrm{W})$ or water-in-oil (W/O) and having size range from 5 to $100 \mathrm{~nm}$. These carriers have been reported to improve the oral bioavailability of drugs. ${ }^{65}$.

Shende, G. et al. $2014^{66}$ reported that Anthralinmicroemulsion gel using Karanj oil for treatment of psoriasis with an objective of improving solubility of the Anthralin. From the results of the present research work it can be concluded that Anthralinmicroemulsion gel containing carbopol 940 as gelling agent prepared with karanj oil can provide a basis for successful design of topical delivery of Anthralin in psoriasis treatment ${ }^{66}$.

b. Nano emulsion: These carriers are thermodynamically stableand transparent systems of oil, water, surfactant and co-surfactant with a droplet size ranging from $20-200 \mathrm{~nm}$. It is a promising tool for drug delivery due to their stability, ease of preparation, and having high solubility of drug molecules. ${ }^{67}$

Ali,M et al. 2012reported thatthe nanoemulsion was stable systemand are practically non-irritating in nature in the organotypic HET-CAM model. An optimized formulation was used to confirm the nonirritation nature by histopathological study using rat

skin. An optimized formulation was takento see the anti inflammatory activity and it was carried out by carragennen induced paw edema. Thus it serves as an alternative and effective treatment for skin diseases such as atopic dermatitis and psoriasis ${ }^{68}$. 


\section{Polymer basedcarrier:}

Carriers made up of Polymeric plays a very important role in drug delivery system for controlled and sustained release of therapeutic agents.They contains natural or synthetic polymer as an important excipients where encapsulation of drug moiety within micro- or nanosystems are within the polymers ${ }^{69}$ .Various classes of polymeric colloidal carriers used in the therapy of psoriasis are discussed below:

1. Self assembled carriers: Carriers are having a complex structure which involves non-covalent interactions formed by spontaneous arrangement of molecular units. At interfacesamphiphilic molecules assemble themselves in the presence of specific solvents. They keep their hydrophobic regions isolated from contact with polar solvents ${ }^{\mathbf{7 0}}$.

a. Dendrimers: Dendrimers are made up of polymeric materials. They have high degree of surface functionality and versatilitydue to their typically symmetrical shape around the core and adopts a spherical three dimensional structure ${ }^{71}$. Dendrimers consist of three structural components ; (a) An initiator core (b) Interior layers composed of repeating units, radically attached to the interior core (c) Exterior attached to the outermost interior generations.

Agrawal ,U.et al. 2013 reported that in controlled and targeted drug delivery hyperbranched

polypropylene imine (PPI) dendrimer plays a very important rolebecause of their mono-dispersity, highdensity of functional group at peripheral, having precise shape and size, surface chemistries. Improves the topical bioavailability of the molecules in a controlled manner. The flux of dithranol has increased and shows to be very effective across the skin of rat. The dithranol loadeddendrimer helpsin targeting drug to the epidermal and dermal sites within the skin, thus creates new approach for controlled and sustained delivery, for the treatment of psoriasis. The PPI loaded into dendrimersenhanced drug retention time in the skin andreductions in skin irritation take place ${ }^{72}$.
b.Micelles: Colloidal systems consist of amphiphilic group their assemblance take place above the critical micelle concentration (CMC) to form a specific core. Polymeric micelles,consist of block copolymercontaningamphiphilic group with different lipophilic and hydrophilic properties ${ }^{73}$.

Maria, L. et al 2014 reported that a stable $0.1 \%$ TAC(tacrolimus) formulation using MPEG-dihex PLA (methoxy-poly(ethylene glycol)-poly(hexylsubstitutedlactides) micelles was successfully developed and characterized. Experiments demonstrated that the $0.1 \%$ micelle formulation significantly increased the cutaneous bioavailability of TAC as compared to Protopic $(0.1 \% \mathrm{w} / \mathrm{w})$. The biodistribution study showed that after application for $12 \mathrm{~h}$, micelles increased TAC delivery into the stratum corneum and viable epidermis. Given that immune cells, responsible for the inflammatory response in psoriatic lesions, are located in this latter layer and the dermis, the results suggested that the micelle formulation might be able to increase clinical efficacy without increased risk of systemic exposure. This study suggests that micelles are innovative, safe biomaterial based nano carriers that enable targeted cutaneous delivery of TAC. Further studies will be performed to optimize the ease of application of the micelle formulation and to test efficacy in vivo, first in a psoriatic skin model and then in patients ${ }^{74}$.

c. Hydrogels: Multicomponent systems consisting of a three-dimensional network of polymer chains and water that fills the space between macromolecules. It can be synthesized in a number of chemical ways which includes like polymerization and parallel cross-linking of multifunctional monomers,synthesis of polymer molecules having reactive groups and their subsequent cross-linking are also involved, various cross-linking agents are also used by reacting polymers with this ${ }^{7576}$.

Sah, K. A et al. 2011methoxsalen entrapped in Microemulsion-based hydrogel serves as effective promoters for the local effect in the skin. The accumulation of methoxsalen in skinenhanced the targeting of the drug without any systemic side effects. It is better vehicle for topical delivery of drug than conventional ${ }^{77}$. 
Particulate carrier: These are polymer based matrix system in which either dispersion of drug takes place or dissolution of drug take place. The drug release take place through diffusion, swelling,or erosion controlled.

a. Nanospheres: Drug entrapment in nanospheres through dispersion in the polymer matrix. Biodegradable or non-biodegradable polymers are used. For controlled or site specific delivery of drugs biodegradable polymer are significantly used as drug delivery systems. Uniform dispersion of drug in the polymer matrix takes place. ${ }^{78}$

Brian, E K. et al. 2012 reported that Paclitaxel loaded tyroSpheresarenon toxic in nature and provide greatly enhanced solubility. It controls the hyperproliferation of keratinocytes therefore Paclitaxel loaded tyro Spheres helps in bringing the system back into equilibrium. Low dose frequency of Paclitaxel and deposition of Paclitaxel into the epidermis takes place and thus have low side effects associated with systemic exposure ${ }^{79}$.

b. Microspheres: These are polymeric based matrix systems with size ranging in micron normally $1 \mu \mathrm{m}$ to $1000 \mu \mathrm{m}$. It providescontrolled and sustained release and reduction in the dosing frequency which improves therapeutic effect and patient compliance. ${ }^{\mathbf{8 0}}$

Ulya, B.et al 2011.It is a novel drug delivery for the safe and effective delivery of drugs including antipsoriatic drugs. Clobetasol propionate-loaded PLGA microspheres were successfully prepared as a topical delivery using $\mathrm{o} / \mathrm{w}$ emulsion using solvent evaporation methodfor psoriasis treat- ment. The drug permeabilityis increased by using emulgels. The clobetasol propionate loaded PLGA microspheres significantly reduce the drug release from the emulgel. There is reduction in the topical and systemic side effects of the drug and the efficiency and efficacy of treatment is increased due to prolonged release of clobetasol propionate from the emulgel containing PLGA microspheres ${ }^{81}$

3.) Capsularcarriers: These are reservoir based system in which the drug is restricted to a reservoir or present within a core which is enclosed within polymeric membrane. Inside the cavity the active substance is present in liquid or solid form or as a molecular dispersion. Capsules utilized as drug delivery carriers can masks the tastes and have controlled release properties. ${ }^{82}$

a. Nanocapsules: These are nanoparticles in nature ,consists of one or more active materials in core and a shell known as protective matrix in which the therapeutic substance may be encapsulate. They hasprotective coating, usually pyrophoric in nature and easily oxidized.Provides sustained release, increase drug selectivity and effectiveness, improved drug bioavailability and reduction in drug toxicity ${ }^{83}$.

Orique and group developed tretinoin-loaded nanocapsules. There is increase drug stability in nanocapsule as reported by Photodegradationstudies . These systems improved half life of tretinoinnanocapsule suspensions as compared to tretinoinmethanolic solution.Thus, nanocapsules act as a promising carrier for tretinoin in treatment of psoriasis. $^{84}$

b. Microcapsules: It is drug delivery system in which very tiny droplets or particles of liquid or solid material are surrounded or coated with a continuous film of polymeric material, ranging in size from 1 to 5,000 microns. Through this technique taste masking of bitter drugs is improved, provides controlled release and sustained action dosage forms, incompatible materials get separated, protection of drug from moisture and light. ${ }^{85}$

4.) Nanogel: Avasatthi, V. et alreported that MTXNLC gel showed the gradual release with more effective eradication of psoriatic manifestations when topically applied. The findings of this formulation pave the way for treatment of psoriasis with the topical colloidal formu- lation of MTX. However, significance of MTX-NLC gel may only be established, when evaluated clinically.

\section{CHALLENGES IN PSORIATIC TREATMENT}

There are several therapeutic agents but stills treatment of psoriasis remains a challenging task due to non-appropriateness of an ideal drug molecule. The major challenges in the psoriasis treatment are elaborated below ${ }^{87}$ : 


\section{Delivery of anti-psoriatic drugs due to Lack of efficient carrier.}

Antipsoriatic drug deliveryhas inherent side effects of drug molecules or their incorporation in the conventional vehicles is improper. There are lots of variation in the physicochemical characteristics of the carrier and of the active molecules used and thus causes variation in absorption ofdrug and efficacy of drug ${ }^{88}$. To overcome the problems associated with conventional vehicles Novel colloidal delivery carriers can be used. The advantages of novel colloidal carriers are protection of entrapped drugs against detrimental external and internal factors, therapeutic drug levels is maintained by controlled drug release for a longer period of time, specific sites of action by passive or active targeting thus ensuring different interaction pathways with target cells away fromsites of their toxicity leading to improvement of the drug therapeutic efficacy and effective internalization ${ }^{89}$.

\section{Inappropriate animal model}

Inappropriate animal model is another challenge in the development of an ideal drug and delivery carrier for the psoriasis treatment which would purely mimic histological and immunophenotypic characteristicsof psoriasis as this disease usually occurs only in humans. Although numerous immunological and genetic animal models have been developed, but none of these models demonstrate all the characteristics of psoriasis with associated limitations. There are some exhaustive reviews available exclusively on animal models of psoriasis ${ }^{\mathbf{9 0}}$. Principally three major animal models are used like spontaneous mutation models, Xenotransplantation model and transgenic model ${ }^{91}$.

\section{FUTURE CONCEPTS}

The concept of general and non-specific immunosuppressant as a first-line therapy for psoriasis should be revised in the light of modalities targeting single cytokines or intracellular key proteins implicated in psoriasis pathogenesis. To improve our understanding ofdisease pathogenesis and of common pathways in psoriasis, psoriatic arthritis or rheumatoid arthritis there is some new modalities that helped us ${ }^{92}$. In the field of dermatology a number of new therapies are approached and clinical practice is done. For psoriatic arthritis ustekinumab was the first anticytokine biologic used exclusively by dermatologists.

Safety and efficacy of directly neutralizing IL-23, without affecting IL-12 and Th1 responses was considered, which was necessary to control tumors and viral infections. Fortherapy of patients with psoriasis the targeting of IL-23a, with $\mathrm{p} 40$, is currently under investigation. This experience is important for IL-23/Th17 and IL-12/Th1 responses in psoriasis and can destroy an old dogma concerning the relevance of Th1 cells in this disease ${ }^{94}$. Approaches primarily used in dermatology are by neutralizing IL-17 or blocking IL-17R. The autoimmune disease psoriasis can be treated by neutralizing the cytokines and its efficacy of antibodies against TNF, IL-17 or IL-23 demonstrate clearly that secreted by Th17 cells, neutrophils and mast cells or by inhibiting the cytokine-mediated activation of these cell populations. Biologics are used for neutralizing Th17 cytokines and prevents extension of Th17 ${ }^{\mathbf{9 5}} \mathbf{9 6}^{\mathbf{9}}$. For the treatment of psoriasisneutralization of Th17-associated cytokine IL-22, which affects keratinocytesis very effective. Alternatively, reduction in the inflammation by administrating cytokines takes place, and prevents Th17 and/or Th1 responses. Administration of IL-4 improved psoriasis inflammation and induction of Th2 responses in a phase $1 / 2$ trial take place ${ }^{9798}$.

In clinical practice of psoriasis oral compounds plays a important role. For patients with multiple sclerosis the use of DMF has new therapeutic approach. Apremilast, increase safety profile and its efficacy and extend the list of oral compounds in psoriasis. A promising approach for systemic or even topical treatment of psoriasis is by directly targeting cytokine receptor signaling pathways with JAK inhibitors ${ }^{99}$ ${ }^{100}$. In many countries we are in the unique position where psoriatic patient has established eight different systemic therapies. To extend our therapeutic spectrum there are at least four upcoming biologics and three oral compounds. We have to understand the mechanisms in non-responders, and those with a loss of response, in order to provide lifelong protection from psoriasis and psoriatic arthritis. Also, the 
advantages and safety issues of combination therapies still have to be studied in more detail. The development of further effective and safe antipsoriatic therapeutics is not yet complete ${ }^{\mathbf{1 0 1} 102}$.

\section{CONCLUSION}

Psoriasis is one of the major chronic skin inflammatory and autoimmune diseases that hinders modern society and being associated with high morbidity factors and still remains incurable. Successful management of psoriasis can be reached by an excessive number of therapeutic agents. Every treatment strategy has multiple and wide-ranging adverse effects. However, conventional pharmacotherapies insufficient for effective treatment of psoriasis; they have several limitations, and have low efficacy. Novel carriers such as liposomes, ethosomes, and lipid nanoparticles etc have been able to carry the majority of antipsoriaticagents andhave improvedtherapeuticpotential. Nanomedicines act as drug carrier provide enhanced therapeutic efficacy with lesser toxicity, dose reduction, drug localization

\section{REFERENCES}

1. Wing ML, Charles MH, Alex W. Design, Synthesis and in Vitro Degradation of a Novel Co-Drug for the Treatment of Psoriasis Wing White 21 School of Pharmacy, University of Reading, Whiteknights, P.O. Box 226, Reading, RG6 6AP, UK 2 School of Pharmacy and Pharmaceutical Sciences, Cardiff University, Cardiff, CF10 3NB, UK; E-Mails: heard@cf.ac.uk (C.M.H.); whiteaw@cf.ac.uk (A.W.W.) 2013; 233.

2. Rahman M, Akhter S, Ahmad J, Mohammad ZA, Sarwar B, Farhan J A.Nanomedicinebased drug targeting for psoriasis: potentials and emerging trends in nanoscale pharmacotherapy $2014 ; 1$.

3. Prohić A, Helppikangas $\mathrm{H}$, Muhović J .Tagetting psoriasis with new therapies. MedicinskiGlasnik 2007; 4: 56- 62.

4. Witman P. Topical therapies for localized psoriasis. Mayo Clin. Proc 2001; 76: $943-$ 949. and drug at specific site. However, mostof the studies lacks clinical outcome in psoriasis thus required the research directed toward the clinical study to establish the fate of nanoparticles as prospective antipsoriaticnanomedicines.

\section{ACKNOWLEDGEMENT}

This research was partially supported by Dr. H.S. Gour University, Sagar, M.P. 470003, India. We thank our Teachers who provided insight and expertise that greatly assisted the research, although they may not agree with all of the interpretations/conclusions of this paper.

We would also like to show our gratitude to the Punjab University for sharing their pearls of wisdom with us during the course of this review, and we thank reviewers for their so-called insights. We are also immensely grateful to our seniors for their comments on an earlier version of the manuscript, although any errors are our own and should not tarnish the reputations of these esteemed persons.

5. Christophers E. Psoriasis-Epidemiology and clinical spectrum. Clin. Exp. Dermatol 2001; 26:314-320.

6. Lomholt G. Prevalance of skin disease in a population: A Census study from the faroe island. Dan med bull 1964; 11:1-7.

7. Green AC. Australian Aborigines ad Psoiasis. Australas. J Deramatol1984;25:18-24.

8. Nickoloff BJ. The immunologic and genetic basis of psoriasis. Arch. Dermatol 1999; 135:1104-1110.

9. Lowes MA, Lew W, Krueger JG. Current concepts in the immunopathogenesis of psoriasis. Dermatol. Clin 2004; 22: 349-369.

10. Adorini L; Trembleau S. Immune deviation towards Th2 inhibits Th1-mediated autoimmune diabetes. Biochem. Soc. Trans 1997; 25:625-629.

11. Hern S, Allen MH, Sousa AR, Harland CC, Barker JN, Levick JR, Mortimer PS. Immunohistochemical evaluation of psoriatic plaques following selective photothermolysis 
of the superficial capillaries. Br. J. Dermatol 2001; 145: 45-53.

12. Naldi L, Gambini,D . The clinical spectrum of psoriasis. Clin. Dermatol. 2007;25:510518.

13. Suresh PK, Singh $P$, Saraf S. Novel topical drug carriers as a tool for treatment of psoriasis: Progress and advances University Institute of Pharmacy, Pt. RavishankarShukla University, Raipur, Chhattisgarh, 492010, India 2013;139.

14. Binderup L, Bram E. Effects of novel vitamin $\mathrm{D}$ analogue (MC903) on cell proliferation and differentiation in vitro and on calciummetabolism in vivo. Biochem Pharmacol 1998; 37:889-895.

15. Krutmann J. Therapeutic photoimmunology: photoimmunological mechanisms in photo(chemo)therapy. J PhotochemPhotobiol B Biol 1998; 44:159- 164

16. Gottlieb S, Hayes E, Gilleaudeau $P$, Cardinale I, Gottlieb AB ,Krueger JG. Cellular actions of etretinate in psoriasis: enhanced epidermal differentiation and reduced cell-mediated inflammation are unexpected outcomes. J CutanPathol 1996; 23: 404-418.

17. Farkas A, KeemenyL, Szony BJ, Bata-Csorgo Z, Pivarcsi A, Kiss M, Szell M., Koreck, A, Dobozy,A. Dithranolupregulates IL-10 receptors on the cultured keratinocyte cell line HaCaT. InflammRes 2001; 50:44- 49

18. Baggott JE, Morgan SL, Sams WM, Linden J. Urinary adenosine and aminoimidazolecarboxamide excretion in methotrexatetreated patients with psoriasis. Arch Dermatol 1999;135: 813-817.

19. Kino $T$, Hatanka $H$, Hashimoto $M$, Nishiyama M, Goto T, Okuhara M, Kohsaka M.,Aoki H Imanaka H. FK506, a novel immunosuppressant isolated from Streptomyces: I. Fermentation, isolation and physico-chemical and biological characteristics. J Antibiot 1987; 40:12491255

20. Borel J F, Feurer C, Gubler H U. A new lymphocyte agent. Agents Actions 1976; 6: $468-475$.
21. Pilkington $T$, Brogden RN. Acitretin: a review of its pharmacology and therapeutic use. Drugs. 1992; 43: 597-627.

22. Tohyama M, Yang L, Hanakawa Y, Dai X, Shirakata Y, Sayama K. IFN-alpha enhances IL-22 receptor expression inkeratinocytes: a possible role in the development of psoriasis. J Invest Dermatol 2012; 132(7):1933-5.

23. Huang SM.; Zhao, H.; Lee, J.I.; Reynolds, K.; Zhang, L.; Temple, R. et al. Therapeutic protein-drug interactions and implications for drug development. ClinPharmacolTher., 2010, 87(4),497-503.

24. Morgan ET. Impact of infectious and inflammatory disease on cytochrome P450mediated drug metabolism and pharmacokinetics. ClinPharmacolTher 2009; 85(4): 434-438.

25. Schmitt C, Kuhn B, Zhang $X$, Kivitz AJ, Grange S. Diseasedrug- drug interaction involving tocilizumab and simvastatin in patients with rheumatoid arthritis. ClinPharmacolTher 2011; 89(5) : 735-40.

26. Garcia P M.E, Stevanovic T, Poubelle PE. New therapies under development for psoriasis treatment. CurrOpinPediatr 2013; 25: 480-487.

27. Reddy M, Davis C, Wong J, Marsters P, Pendley C, Prabhakar U. Modulation of CLA, IL-12R, CD40L, and IL- 2Ralpha expression and inhibition of IL-12- and IL-23- induced cytokine secretion by CNTO 1275. Cell Immunol 2007; 247(1):1-11.

28. Leonardi $\mathrm{C}$, Matheson $\mathrm{R}$, Zachariae $\mathrm{C}$, Cameron G, Li L, Edson-Heredia, E. et al. Anti-interleukin-17 monoclonal antibody ixekizumab in chronic plaque psoriasis. $\mathrm{N}$ EnglJMed 2012; 366: 1190-1199.

29. Langley RG, Papp K, Gottlieb AB, Krueger GG, Gordon KB, Williams D. et al. Safety results from a pooled analysis of randomized, controlled phase II and III clinical trials and interim data from an open-label extension trial of the interleukin-12/23 monoclonal antibody, briakinumab, in moderate to severe psoriasis. J EurAcadDermatolVenereol 2013; 27: 1252-1261. 
30. Lee E, Trepicchio WL, Oestreicher JL, Pittman D, Wang F, Chamian $F$ et al. Increased expression of interleukin 23 p19 and $\mathrm{p} 40$ in lesional skin of patients with psoriasis vulgaris. J ExpMed 2004; 199(1): 125-30.

31. Krueger JG, Fretzin S, Suarez-Farinas M, Haslett PA, Phipps KM, Cameron GS. et al. IL-17A is essential for cell activation and inflammatory gene circuits in subjects withpsoriasis. J Allergy ClinImmunol 2012; 130: 145-154.

32. Papp KA, Langley RG, Sigurgeirsson B, Abe M, Baker DR, Konno P. et al. Efficacy and safety of secukinumab in the treatment of moderate-to-severe plaque psoriasis: a randomized, double-blind, placebo-controlled phase II dose-ranging study. Br J Dermatol 2013; 168: 412-421.

33. Leonardi $\mathrm{C}$, Matheson $\mathrm{R}$, Zachariae $\mathrm{C}$, Cameron G, Li L, Edson-Heredia E. et al. Anti-interleukin-17 monoclonal antibody ixekizumab in chronic plaque psoriasis. N Engl J Med 2012; 366: 1190-1199.

34. Papp KA, Leonardi C, Menter A, Ortonne,JP, Krueger JG, Kricorian G. et al. Brodalumab, an anti-interleukin- 17-receptor antibody for psoriasis. N Engl J Med 2012; 366: 11811189.

35. Reich K, Ortonne JP, Gottlieb AB. et al. Successful treatment of moderate to severe plaque psoriasis with the PEGylated Fab0 certolizumabpegol: results of a phase II randomized, placebo-controlled trial with a re-treatment extension. Br J Dermatol 2012; 167: 180-190.

36. World Health Organization Expert committee on biological standardization Guidelines on evaluation of similarbiotherapeutic products (SBPs). Geneva, Switzerland. October 19-23, 2009.http://www.who.int/biologicals/areas/bi ological_therapeutics/BIOTHERAPEUTICS FOR_WEB_22APRIL2010.pdf. Accessed February 11, 2014.

37. Page CP, Spina D. Phosphodiesterase inhibitors in the treatment of inflammatory diseases. Hand ExpPharmacol 2011; 204: 391-414.
38. Moore AR, Willoughby DA. The role of cAMP regulation in controlling inflammation. ClinExpImmunol 1995; 101:387-389.

39. Papp KA, Menter A, Strober B. et al. Efficacy and safety of tofacitinib, an oralJanus kinase inhibitor, in the treatment of psoriasis: a Phase $2 \mathrm{~b}$ randomizedplacebocontrolled dose-ranging study. Br J Dermatol 2012; 167:668-677.

40. Ports WC, Khan S, La S, Lamba M, Bolduc C, Bissonnette R. et al. A randomized phase 2a efficacy and safety trial of the topical Janus kinase inhibitor tofacitinib in the treatment of chronic plaque psoriasis. $\mathrm{Br} \mathrm{J}$ Dermatol 2013; 169: 137-145.

41. Kaminska B, Swiatek-MK. Targeting signaling pathway with small molecules to treat autoimmune disorders. Expert Rev ClinImmunol 2008; 4: 93-112.

42. Fishman P, Bar-Yehuda S, Liang BT. et al. Pharmacological and therapeutic effects of A(3) adenosine receptor agonists. Drug Discov Today 2012; 17:359-366.

43. David M, Akerman L, Ziv M. et al. Treatment of plaque-type psoriasis with oral CF101: data from an exploratory randomized phase 2 clinical trial. J EurAcadDermatolVenereol 2012; 26: 361367

44. Mehnert W, Mader K. Solid lipid nanoparticles: Production, characterization and applications. Adv. Drug Deliv. Rev 64(Suppl) 2012; 83-101.

45. Kamboj S, Saini V, Magon N, Bala S, Jhawat V.Vesicular drug delivery systems. A novel approach for drug targeting 2013; 92-95.

46. Sharm J, Kalra S,Sharma A, Ran S. Colloidal drug carriers. Internet J. Fam.Pract 2010; 9.

47. Singh MR, Pradhan K, Singh D. Lipid matrix systems with emphasis on lipid microspheres: potent carriers for transcutaneous delivery of bioactives. Curr.DrugDeliv 2012; 9: 243254.

48. Rawat M, Singh D, Saraf S, Saraf S. Nanocarriers: promising vehicle forbioactive drugs. Biol. Pharm. Bull 2006; 29: 17901798. 
49. Cevc G, Blume G. Lipid vesicles penetrate into intact skin owing to the transdermal osmotic gradients and hydration force. Biochem, BiophysActa 1992; 1104: 226232.

50. Trotta M, Peira E, Carlotti ME, Gallarate M. Deformable liposomes for dermal administration of methotrexate. Int. J. Pharm 2004;270: 119-125.

51. Constanzo R, De P T, Ihlo JE, Hager AA, Farach HA, Poole CP, Knight JM. ESR study of order and dynamics in lecithin liposomes with highcholesterol content. Spectrochim. Acta1994; 203-208.

52. Pathomthat S, Phensri T, Uracha. Physicochemical characteristics of methotrexateentrapped oleic acid-containing deformable liposomes for in vitro transepidermaldeliverytargeting psoriasis treatment. Pharmaceutical Nanotechnology 2012; 433-434.

53. Saraswat A, Agarwal R, Katare OP. A randomized, double-blind, vehicle-controlled study of a novel liposomal dithranol formulation in psoriasis. Journal of Dermatological Treatment 2007; 18: 40-45.

54. Dubey V, Mishra D, Jain NK, Dutta T, Nahar M, Saraf DK. Transdermal drug delivery of antipsoriatic agent via ethanolic liposomes. J. Control. Release 2007; 123: $148-154$.

55. Rakesh R, Anoop KR. Ethosomes for transdermal and Topical drug Delivery. International Journal of Pharmacy and Pharmaceutical Sciences., Vol 4, Suppl 3, 2012; 17-24

56. Vyas S P, Subheder R, Jain S. Development and characterization of emulsomes for sustained and targeted delivery of an Antiviral agent to liver. Journal Of Pharmacy Pharmacology 2006; 58(3): 321-326.

57. Gupta S, Vyas SP. Development and characterization of amphotericin $\mathrm{B}$ bearing emulsomes for passive and active macrophage targeting. Journal of Drug Targeting 2007;15(3):206-217.

58. Raza K, Katare OP, Setia A, Bhatia A, Singh B.Improved therapeutic performance of dithranol against psoriasis employing systematically optimized nanoemulsomesDrug Delivery Research Group., University Institute of Pharmaceutical Sciences., UGC-Centre of Advanced Study, Panjab University, Chandigarh 160014, India., 2012; 613-616.

59. Agarwal S, DR.V Kamala. Advances in novasome technology- A Review. Int J App Pharm Vol 5, Issue 1, 2013; 1-4

60. Bunjes H. Structural properties of solid lipid based colloidal drug delivery systems, Curr. Opin. Colloid Interface Sci 2011; 16: 405441.

61. Touitou E, Shaco-Ezra N, Dayan N. et al. Dyphylline liposomes for deliveryto the skin. J Pharm Sci 1992; 81:131-4.

62. Zhang X, Liu J, Qiao H, Liu H, Ni J, Zhang W, Shi Y. Formulation optimization of dihydroartemisinin nanostructured lipid carrier using response surface methodology,Powder. Technol 2010; 197: 120-128.

63. Shinde G, Rajesh KS, Prajapati N, Murthy RS. Formulation, development and characterization of nanostructured lipid carrier (NLC) loaded gel for psoriasis. Der Pharmacia Lettre 2013; 5 (4): 13-25.

64. Agrawal Y, Petkar KC, Sawant KK. Development, evaluation and clinical studies of Acitretin loaded nanostructured lipid carriers for topical treatment of psoriasis. International Journal of Pharmaceutics 2010; 401: 93-102.

65. Shaji J, Reddy M S. Microemulsion as drug delivery system. Pharma times 2004; 36: $17-$ 24.

66. Alvarez-Figueroa MJ, Blanco-Mendez J. Transdermal delivery of methotrexate: iontophoretic delivery from hydrogels and passive delivery from microemulsions. Int. J. Pharm 2001; 215: 57-65.

67. Shah $P$, Bhalodia D, Shelat P. Nanoemulsion: A pharmaceutical review. Syst Rev Pharm 2010;1: 24-32

68. Sajid MA, Sarfaraz M A, Faisal I, Masoom RS. Topical nanoemulsion of turmeric oil for psoriasis. Characterization, ex vivo and in 
vivo assessment. International Journal of Drug Delivery 2012; 4: 184-197.

69. Liechty WB, Kryscio DR, Slaughter BV, Peppas NA. Polymers for drug delivery systems. Ann. Rev. Chem Biomol. Eng 2010; 1: 149-173.

70. Tekade RK, Kumar PV, Jain NK. Dendrimers in oncology: an expanding horizon. Chem Rev 2009; 109: 49-87.

71. Tripathy S, Das MK. Dendrimers and their Applications as Novel Drug Delivery Carriers Journal of Applied Pharmaceutical Science 2013; 3 (09): 142-149.

72. Agrawal U, Kumar NM, Gupta U, Jain NK. Hyperbranched dendritic nano-carriers for topical delivery of dithranol. J Drug Target, Early Online 2013; 1-10.

73. Torchilin VP. Structure and design of polymeric surfactant-based drug delivery systems. J. Control. Release 73 2001; 137172.

74. Maria L, Karine M, Michael M, Robert G, Yogeshvar NK. Polymeric Micelle Nanocarriers for the Cutaneous Delivery of Tacrolimus. A Targeted Approach for the Treatment of Psoriasis Mol. Pharmaceutics 2014; 11: 2989-3001.

75. Amin S, Rajabnezhad S Kohli K. Hydrogels as potential drug delivery systems. Sci. Res. Essays 3. 2009; 1175-1183

76. Enas MA. Hydrogel: Preparation, characterization, and applications. A review Journal of Advanced Research 2015; 6: 105121

77. Sah KA, Jain SK, Pandey RS. Microemulsion based hydrogel formulation of methoxsalen for the effective treatment of psoriasis. Asian J Pharm Clin Res Vol 4, Issue 4,2011; 140-145

78. Carino GP, Jacob JS, Mathiowitz E. Nanosphere based oral insulin delivery. J. Control. Release 2000; 65: 261-269.

79. Brian E K, Larisa S, Zheng Z, Marissa L, Joachim K, Bozena B, Michniak-K. Development of paclitaxel-TyroSpheres for topical skin treatment.
80. Khan S, Tiwari T, Rao A, Joshi N, Dubey BK, Microspheres Journal of Controlled Release, a review WJPPS 2012; 125-145

81. Ulya $B$, Tangül $S$, Nilüfer $T$, Microparticulate Based Topical Delivery System of ClobetasolPropionateAAPS. PharmSciTech Vol. 12, No. 3, September 2011.

82. Letchford $\mathrm{K}$, Burt $\mathrm{H}$. A reviewof the formation and classification of amphiphilic block copolymer nanoparticulate structures: micelles, nanospheres, nanocapsulesandpolymersomes. Eur. J. Pharm. Biopharm 2007; 65: 259-269.

83. Atteno $M$, Peluso $R$, Costa $L$. et al. Comparison of effectiveness and safety of infliximab, etanercept, and adalimumab in psoriatic arthritis patients who experienced an inadequate response to previous diseasemodifying antirheumatic drugs. Clin Rheumatol 2010; 29(4): 399-403.

84. Mora HCE, Fessi H, Elaissari A. Polymerbased nanocapsules for drug delivery. International Journal of Pharmaceutics 2010; 385: 113-142

85. Ourique AF, Pohlmann AR, Gutees SS, Beck RC. Tretinoin-loaded nanocapsules:preparation, physicochemical characterization, and photostability study. Int. J.Pharm 2008; 352: 1-4.

86. Boinpally RR, Zhou SL, Devraj G. et al. Iontophoresis of lecithin vesicles of cyclosporine A. Int J Pharm 2004; 274:18590

87. Schon MP. Animal models of psoriasis: a critical appraisal. Exp. Dermatol 2008;17: 703-712.

88. Jean J, Pouliot R. In vivo and in vitro models of psoriasis, in: Daniel Eberli (Ed.). Tissue Engineering 2010; 359-382.

89. Mizutani H,Yamanaka K, Konishi K, Murakami T. Animal models of psoriasis and pustular psoriasis. Arch. Dermatol. Res 2003; 295: S67-S68.

90. Zollner TM, Renz H, Igney FH, Asadullah K. Animal models of T-cell mediatedskin diseases. Bioessays 2004; 26: 693-696. 
91. Guerrero AS, Garcia M, Murillas R, Retamosa LN et al. Development of a bioengineered skin-humanized mouse model for psoriasis: dissecting epidermallymphocyte interacting pathways. Am. J. Pathol 2010; 177: 3112-3124.

92. Heiberg MS, Koldingsnes W, Mikkelsen K et al. The comparative one-year performance of anti-tumor necrosis factor alpha drugs in patients with rheumatoid arthritis, psoriatic arthritis, and ankylosing spondylitis: results from a longitudinal, observational, multicenter study. Arthritis Rheum 2008; 59(2): 234-40.

93. Spadaro A, Ceccarelli F, Scrivo R, Valesini G. Life-table analysis of etanercept with or without methotrexate in patients with psoriatic arthritis. Ann Rheum Dis 2008; 67(11):1650-1.

94. Antoni C, Krueger GG, de Vlam Ket al. Infliximab improves signs and symptoms of psoriatic arthritis: results of the IMPACT 2 trial. Ann Rheum Dis 2005; 64(8):1150-7.

95. Scarpa R, Peluso R, Atteno $M$ et al. The effectiveness of a traditional therapeutical approach in early psoriatic arthritis: results of a pilot randomised 6-month trial with methotrexate. ClinRheumatol 2008; 27(7): 823-6.

96. Willkens RF, Williams HJ, Ward JR et al. Randomized, double-blind, placebo controlled trial of low-dose pulse methotrexate in psoriatic arthritis. Arthritis Rheum 1984; 27(4): 376-81.

97. Kingsley GH, Kowalczyk A, Taylor H et al. A randomized placebo-controlled trial of methotrexate in psoriatic arthritis. Rheumatology (Oxford) 2012; 51(8): 136877.

98. Ravindran V, Scott DL, Choy EH. A systematic review and meta-analysis of efficacy and toxicity of disease modifying anti- rheumatic drugs and biological agents for psoriatic arthritis. Ann Rheum Dis 2008; 67(6): 855-9. 165.
99. Baranauskaite A, Raffayova H, Kungurov $\mathrm{NV}$ et al. Infliximab plus methotrexate is superior to methotrexate alone in the treatment of psoriatic arthritis in methotrexate-naive patients: the RESPOND study. Ann Rheum Dis 2012; 71(4): 541-8.

100. Atzeni F, Boccassini L, Antivalle M, Salaffi F, Sarzi-Puttini P. Etanercept plus ciclosporin versus etanercept plus methotrexate for maintaining clinical control over psoriatic arthritis, a randomised pilot study. Ann Rheum Dis2011; 70(4): 712-4.

101. Revicki D, Willian MK, Saurat JH et al. Impact of adalimumab treatment on healthrelated quality of life and other patientreported outcomes: results from a 16-week randomized controlled trial in patients with moderate to severe plaque psoriasis. $\mathrm{Br} \mathrm{J}$ Dermatol 2008; 158(3): 549-57.

102. Brimhall AK, King LN, Licciardone JC, Jacobe H. Menter A. Safety and efficacy of alefacept, efalizumab, etanercept and infliximab in treating moderate to severe plaque psoriasis: a meta-analysis of randomized controlled trials. Br J Dermatol 2008;159(2): 274-85.

103. Roberson, Anne M. Bowcockemail Psoriasis genetics: breaking the barrier,Division of Human Genetics, Department of Genetics, Washington University School of Medicine, 4559 Scott Avenue, St. Louis, Missouri. 63110, USA. Fig 2 pg no 417.

104. Chris B. Russell.; David A. Martin.; Jennifer E. Towne.;James G. Krueger.; Michelle A. Lowes. The IL-23/T17 pathogenic axis in psoriasis is amplified by keratinocyte responses. Volume 34, Issue 4, 2013, p174181.

105. Elisha D.O. Roberson, Anne M. Bowcockemail Psoriasis genetics: breaking the barrier,Division of Human Genetics, Department of Genetics, Washington University School of Medicine, 4559 Scott Avenue, St. Louis, Missouri. 63110, USA. Fig 1 p 416. 
